\title{
ЗОВНІШНЬОПОЛІТИЧНА ІДЕНТИЧНІСТЬ \\ АМЕРИКАНЦВ У КАРИКАТУРИСТИЦІ США \\ ПОЧАТКУ ХХ ст. «СВІТОВИЙ ПОЛІЦЕЙСЬКИЙ» Л. ДЕЛРІМПЛА
}

Стаття аналізує особливості репрезентації зовнішньої політики американського президента Т. Рузвельта у карикатурі Л. Делрімпла «Світовий поліцейський». Авторський аналіз карикатури проливає світло на ставлення американців до нової ролі США як світового поліцейського, яку вони перебрали на себе відповідно до Поправки Рузвельта до доктрини Монро. Дослідження біографії Л. Делрімпла, історії журналу «Judge», аналіз конкретно-історичного контексту карикатури дає можливість розглядати їі як важливе джерело до історії зовнішньої політики США зламу XIX -XX ст., а також як репрезентацію і водночас інструмент конструювання зовнішньополітичної самоідентифікації американців.

Ключові слова: зовнішня політика, ідентичність, карикатура, Луїс Делрімпл, Теодор Рузвельт, США.

Постановка проблеми. У вітчизняній історіографії не так багато досліджень, присвячених історії зовнішньої політики США кінця XIX - початку XX ст. Більшість із них стосуються ї1 політичних, ідеологічних і дипломатичних аспектів. Праць, які досліджували б історію американської зовнішньої політики 3 соціокультурної точки зору, зокрема ії репрезентації візуальними засобами, ще менше.

Дослідження політичної карикатури надає можливість простежити рецепцію тих чи інших зовнішньополітичних кроків держави громадською думкою і водночас процес конструювання цієї думки художніми засобами і прийомами, застосованими на малюнках. Візуалізації карикатуристів спонукали американців до оціночних суджень щодо ролі і місця США у світі, питань імперії, відносин з окремими країнами і частинами світу тощо. Тож політична карикатура $є$ цінним джерелом для розуміння стереотипів сприйняття американцями зовнішньої політики власної держави.

Питльована Лілія Юріївна, кандидат історичних наук, доцент, доцент кафедри світової історії нового і новітнього часу, Український католицький університет, м. Львів.

(С Питльована Л.Ю., 2018 
Метою дослідження $є$ аналіз репрезентації зовнішньої політики Т. Рузвельта у карикатурі Л. Делрімпла «Світовий поліцейський» (1905) у контексті конструювання зовнішньополітичної ідентичності американців кінця XIX - початку XX ст.

Аналіз попередніх досліджень. Серед робіт, присвячених вивченню американської зовнішньої політики кінця XIX початку XX ст. варто виділити дослідження молодих науковців К. Касаткіної, I. Лукач [3; 5]. Авторка даної статті теж зверталася до вивчення особливостей зовнішньої політики США згаданого періоду [6; 8]. Майже відсутні дослідження, які висвітлювали б проблему репрезентації зовнішньої політики США у політичній карикатурі [7]. Існують окремі зарубіжні дослідження, присвячені аналізу візуального відображення окремих періодів або нюансів зовнішньої політики США згаданого періоду. Окремо хотілося б виділити монографію Девіда Броді «Візуалізація американської імперії: орієнталізм та імперіалізм на Філіппінах», яка на основі численних джерел, в тому числі карикатур, аналізує особливості імперського світогляду американців [10]. Цікавими $є$ роботи російської дослідниці Вікторії Журавльової, які присвячені імагологічним аспектам російсько-американських відносин зламу XIX - XX ст. і містять нові методологічні підходи до дослідження політичної карикатури як джерела до вивчення міжнародних відносин і зовнішньої політики держав. Особливо із соціокультурної точки зору, в контексті зовнішньополітичної самоідентифікації держав крізь призму образу Іншого [1; 2]. Втім досліджень, які безпосередньо вивчали б репрезентацію окремих періодів зовнішньої політики США, зокрема у карикатурі, обмаль. Серед найпримітніших варто згадати працю Ричарда Маршалла, присвячену життю i часу Т. Рузвельта, що містить понад 250 карикатур, присвячених різним аспектам життя і діяльності президента, які однак відіграють у згаданому дослідженні в основному ілюстративну роль [21].

Виклад основного матеріалу. Карикатура Луїса Делрімпла (Louis Dalrymple) (1861(65?66?)-1905) «Світовий поліцейський» («The world's constable») вперше була опублікована в американському сатиричному журналі «Judge» 14 січня 1905 р. [14]. Аналіз цієї карикатури у контексті імагології міжнародних відносин вимагає виявлення таких даних і врахування наступних нюансів: інформація про автора, спосіб подачі матеріалу, оцінка мови і 
символіки карикатури; iï цільове призначення та аудиторіяреципієнт; залежність карикатуристів від думки редактора i загальної політики періодичного видання [2, с. 68].

Історія американських сатиричних журналів «Judge» $\mathrm{i}$ «Puck» тісно пов'язана між собою. На початок $1880-$ х років заснований американським карикатуристом Джозефом Кепплером (Joseph Keppler) (1838-1894) щотижневик «Puck» вже користувався чималою популярністю у читачів. Але після низки непорозумінь $\mathrm{i}$ сварок в колективі видання влітку та восени 1881 р. група художників на чолі з Джеймсом Альбертом Велсом (James Albert Wales) (1852-1886) заснувала часопис «The Judge». Дж. Велс став відомим ще за своїми роботами в «Puck», зокрема, за серією портретних карикатур «Puck's Pantheon», присвячених американським політикам. Співзасновниками «Judge» стали також відомий видавець Френк Тузі (Frank Tousey) (1853-1902) та письменник ірландського походження Джордж Джессоп (George H. Jessop) (1852-1915). Журнал виходив щотижня на шістнадцяти сторінках, обкладинка і середні сторінки виконувалися у техніці кольорової літографії.

Невдовзі після потужного старту «The Judge» зазнав фінансових труднощів, які 1885 р. змусили Велса продати журнал і повернутися в «Puck». Однак незабаром за підтримки Республіканської партії «The Judge» став одним із найпопулярніших видань свого жанру. Вже на початку 90-х рр. ХІХ ст. він виходив накладом у 50 тисяч, а 1912 р. - у 100 тис. примірників. Кількість передплатників тепер уже просто «Judge» перевищила аналогічний показник у «Puck» [13, p. 281]. На жаль, Дж. Велс не дожив до тріумфу свого дітища - він помер у Нью-Йорку у віці 34 років від серцевого нападу. За визнанням сучасників, Дж. Велс став єдиним народженим у США карикатуристом нової школи, який досягнув видатного успіху [28, р. 323].

Тиражі «Judge» різко скоротилися під час Великої депресії, а ціна знизилася до 10 центів за номер. 31932 р. часопис став виходити у форматі щомісячника за ціною 15 центів. Останній номер журналу вийшов друком 1947 р. [19].

«Judge» вже 3 перших своїх випусків спеціалізувався на політичній карикатурі, дуже часто спрямованій проти Демократичної партії. Особливо показовою була серія карикатур, яка критикувала В. Мак-Кінлі під час президентської кампанії 1896 р. 
На зламі XIX - XX століть журнал відрізнявся поміркованою сатирою як соціального, так і політичного характеру. Будучи прихильним до демократичних реформ у суспільстві, соціальної рівності, боротьби 3 корупцією тощо, журнал, тим не менше, впродовж 1896 - 1904 років активно критикував представника популістського крила Демократичної партії В. Дж. Брайяна, ідеї якого здалися редакції «Judge» надто радикальними. Неоднозначним було і сприйняття журналом постаті і діяльності президента-республіканця Теодора Рузвельта (1901-1909), особливо його зовнішньої політики.

Починаючи з 1880-х і до 1905 р., колоритні карикатури Луїса Делрімпла були невід’ємною частиною американських сатиричних журналів. Він був одним із найвідоміших карикатуристів свого часу [16, p. 3]. Про художника відомо не надто багато. Він народився у Кембриджі (штат Іллінойс) у сім’ї фермера, а після того, як у нього виявився хист до малювання, навчався у Лізі студентів-художників Нью-Йорка (Art Students League of New York), яка відрізнялася демократизмом студентського контингенту, навчальних програм і цін на навчання, а з 1883 р. - у Пенсільванській академії образотворчих мистецтв (Pennsylvania Academy of the Fine Arts), найстарішій художній школі США.

Л. Делрімпл розпочав свою професійну кар'єру 1883 р. 3 окремих публікацій у «Judge», того ж року він став головним карикатуристом нью-йоркської «The Daily Graphic: An Illustrated Evening Newspaper». Упродовж 1886 - 1901 pр. його карикатури регулярно з'являлися у «Puck». Втім прямий незговірливий характер Л. Делрімпла змушував його часто міняти місця праці. 1901 р. він переходить в «St. Louis Post-Dispatch» (Miccypi), працює у виданнях Філадельфії і Пітсбурга, а з 1903 р. - у «Chicago Tribune». Останнім місцем праці Л. Делрімпла став «Judge» [15 p. 74]. Невдачі особистого життя негативно вплинули на стан здоров'я художника, і він помер у розквіті творчих сил.

Аналіз карикатур Л. Делрімпла дає можливість твердити про його прихильність до основних реформ Т. Рузвельта, які стали піком Прогресивної ери, покликаної «сміливо скеровувати державний корабель від туманної мли дев'ятнадцятого сторіччя в яскраве сонячне світло двадцятого» [24, р. XII]. «Несправедливо, 
якщо багаті стають багатшими, а бідні біднішими» [26], - заявляв президент. Громадська думка на загал підтримувала політику соціальних, політичних і правових реформ, спрямованих на усунення нерівності у суспільстві.

Не менш радикальні перетворення відбулися за часів президентства Т. Рузвельта й у зовнішній політиці США. Завершення освоєння континентальної частини Сполучених Штатів спонукало американців до пошуку нових заокеанських фронтирів. 3 початку 80-х років XIX ст. США активізували свою політику в азійсько-тихоокеанському регіоні, у Центральній i Південній Америці. Були приєднані Східне Самоа, Гаваї, а після війни з Іспанією - Філіппіни, Гуам.

Нові горизонти зовнішньої політики вимагали оновлення іiі підставових ідеологічних засад. «Розмовляй м'яко, але тримай в руках великий кийок, і ти далеко зайдеш», - приказка, яку Т. Рузвельт вперше оприлюднив 1900 р., ще будучи губернатором штату Нью-Йорк. Цей новий принцип силової зовнішньої політики стосувався, передусім, країн Карибського басейну, Центральної і Південної Америки. Після завершення війни 1898 р. 3 Іспанією Сполучені Штати здобули стійку перевагу у Карибському регіоні, остаточно затверджену поправкою Платта 1901 р. Залишивши за собою право втручатися у справи Куби, адміністрація Т. Рузвельта фактично окреслила для себе значно ширшу сферу впливу. Тепер уже йшлося не про доктрину Монро першої третини XIX ст. в іï ізоляціоністському розумінні, а про доктрину зламу XIX - XX ст., сфера застосування якої розширилася настільки, що перетворила ії на індульгенцію американській гегемонії в Західній півкулі. Доктрина почала виправдовувати американське втручання у справи інших держав не тільки у випадку існування реальної загрози для країни, але й евентуально, при одній лише появі можливості подібного виклику [4 , с. 27]. Вже на 1898 р. американці виходили з того, що доктрина, як зауважував професор Альберт Херт, не належить до 10 заповідей, отже, іiі можна розглядати як доцільну лише доти, доки вона відповідає національним інтересам США [17, p. 485].

У грудні 1904 р., після перемоги на президентських виборах, T. Рузвельт оголосив т. зв. Поправку до доктрини Монро (Roosevelt Corollary to the Monroe Doctrine). Поправка до 
доктрини Монро Т. Рузвельта, поза іншим, декларувала перебирання Сполученими Штатами на себе ролі «світового поліцейського»: «Безперервні незаконні дії або прояви безсилля, що призводять до загального ослаблення уз цивілізованого суспільства, чи то в Америці чи будь-де, врешті вимагають втручання з боку якоїсь цивілізованої держави. У Західній півкулі дотримання Сполученими Штатами доктрини Монро може змусити їх, можливо і всупереч своїй волі, за обурливих обставин порушення законності або прояву безсилля, до виконанні обов'язків міжнародної поліцейської держави» [23]. Поправка Рузвельта до доктрини Монро відкрила шлюзи для численних військових втручань, особливо в країнах Латинської Америки [8, с. 161].

Назва, змістове наповнення, композиція, символізм, метафори й алюзії карикатури Л. Делрімпла покликані якомога образніше донести до читача дві взаємопов'язані ідеї американської зовнішньої політики - доктрину Монро та Доповнення Рузвельта до доктрини Монро 1904 р.

Візуально карикатура репрезентує президента Т. Рузвельта як велетня, що височіє над світом. Його славнозвісний «великий кийок» - найбільший за розміром об'єкт на малюнку. Дія його охоплює усю земну кулю, на що вказує слід у повітрі. Паперовий сувій із написом «Арбітраж», який тримає Т. Рузвельт під лівою рукою, символізує його владу в посередництві міжнародних суперечок. Загальне враження у читача від постаті президента на карикатурі - відчуття потужної сили, якою є США, і їх домінування над іншими країнами.

Одягнений у форму поліцейського Рузвельт міцно стоїть обома ногами на території Сполучених Штатів, за його плечима височіє будівля Білого дому, який символізує державну владу. Територія США та постать президента розділяють світ на дві великі частини: ліворуч Рузвельта - народи Свропи, Далекого Сходу, праворуч - Азії, Центральної і Південної Америки, Океанії.

Оціночне ставлення Л. Делрімпла щодо політики Т. Рузвельта проглядається не одразу. Самого президента у ролі світового поліцейського художник і не засуджує, і особливо не підтримує. Однак спосіб репрезентації країн і народів, на яких спрямована 
політика Рузвельта, засвідчує уважному глядачеві доцільність поліцейського втручання США, його обгрунтованість. Як серед представників Східної, так і Західної півкулі панує розбрат, суперечки, взаємні претензії, непорозуміння і розгубленість. Усі вони апелюють до США у надії знайти підтримку у розв'язанні своїх проблем.

Великий кийок поліцейського-Рузвельта 3 написом «Нова дипломатія» невипадково нависає безпосередньо над країнами Західної півкулі. Л. Делрімпл підкреслює, що саме проблемні ситуації у латиноамериканських країнах спричинили проголошення Поправки Рузвельта до доктрини Монро.

Так, у грудні 1902 р. Венесуела відмовилася виплачувати свої борги Великій Британії, Німеччині та Італії. Президент Венесуели С. Кастро розраховував на доктрину Монро i втручання у ситуацію США. Т. Рузвельт вбачав у реалізації доктрини на теренах Північної та Південної Америки гарантію майбутнього універсального миру в Західній півкулі, можливість зміцнення незалежності малих держав Нового світу. Доктрина Монро передбачала втручання США лише за умови територіальних захоплень європейців в Америці. Однак остерігаючись, що невиконання своїх боргових зобов'язань Каракасом і низкою інших країн може-таки спровокувати територіальне втручання європейських країн-кредиторів, Рузвельт вирішив діяти на запобігання. Військово-морський флот США був відправлений до берегів Венесуели, яка була взята у блокаду британськими i німецькими кораблями. Погрожуючи війною у випадку висадки європейського десанту на землю Венесуели, Т. Рузвельт сприяв вирішенню питання повернення іiі боргів шляхом переговорів. Берлін і Лондон були змушені пристати на арбітражні пропозиції США. Таким чином, було створено новий прецедент, коли приводом для реалізації доктрини Монро стали не територіальні захоплення європейців у Західній півкулі, а потреба стабілізувати економічну і політичну ситуацію в країнах Центральної і Південної Америки задля запобігання таких захоплень [18, p. 484-485].

Серед представників Західної півкулі Л. Делрімпл зображає як збірних персонажів, як от «Азія», «Центральна Америка», так i конкретно ідентифікованих. На одному з тих, хто звертається за допомогою до поліцейського, бачимо напис «США vs Колумбія». 
Персонаж стоїть до Рузвельта найближче з усіх, чим художник підкреслює, що криза в американсько-колумбійських відносинах через Панаму була одним із перших втілень нового зовнішньополітичного курсу президента. Обрана США поліцейська місія вимагала можливості швидкого реагування військово-морських сил США в межах американського континенту, зокрема, передислокування його 3 Тихого океану в Атлантичний, i навпаки. Тож Рузвельт акцентував увагу на необхідності побудови міжокеанського каналу, яка стала можливою після проголошення незалежності Панами від Колумбіі 1903 р. і визнання нової країни Сполученими Штатами [25]. На малюнку Л. Делрімпла представник Колумбії апелює до Рузвельта зі згаданого приводу, адже всі спроби Боготи змінити ситуацію ні до чого не призвели. Відносини Колумбії зі США та Панамою довший час залишалися напруженими.

У когорті націй, які безпосередньо підпадають під дію «нової дипломатії» Рузвельта, особливе місце посідають Філіппіни, представник яких є єдиним з усіх персонажів Західної півкулі, який має у руках зброю. Після придбання островів Сполученими Штатами по завершенні війни з Іспанією Філіппіни ще тривалий час, до 1902 р., вели запеклу боротьбу з американцями. Окремі спалахи протистояння тривали аж до 1913 р. Опущена додолу рушниця філіппінця символізує припинення боротьби остров'янами, однак невдоволений вираз обличчя філіппінця свідчить про те, що він і досі не змирився зі статусом залежної від США території. Сам Т. Рузвельт був активним поборником захоплення Філіппін ще з часу перебування на посаді заступника міністра військово-морського флоту в адміністрації В. Мак-Кінлі. Приєднання островів у статусі залежної території перетворило США в імперіалістичну державу, що у цей час означало підвищення іiі статусу на міжнародній арені, і відкрило тихоокеанську еру в американській зовнішній політиці [20, р. 46-49]. Варто зауважити, що окупація Філіппінських островів, які стали військово-морською базою американському флоту, дала не лише переваги Сполученим Штатам щодо використання сучасних військово-морських баз, а й породила низку проблем, пов'язаних 3 гарантуванням їх безпеки [6, с. 96].

Щодо Бразилії, то вона впродовж 90-х років XIX ст. потерпала від внутрішньої нестабільності, численних селянських повстань, 
збройних конфліктів між мілітаристами і повстанцями. У 1899 1903 рр. територіальна суперечка між Бразилією і Болівією вилилась у відкритий прикордонний конфлікт за володіння каучуконосними районами i золотими родовищами. Тож на малюнку Л. Делрімпла представник Бразилії теж звертається зі своїми проблемами до новоявленого Рузвельта-поліцейського.

Невипадково єдиним ідентифікованим представником Близького і Середнього Сходу на карикатурі Делрімпла виступає Туреччина. Ще 1898 р., напередодні своєї відправки на Кубу, Т. Рузвельт заявив: «Іспанія і Туреччина - це дві держави, з якими я хотів би покінчити більше, ніж з будь-якими іншими у світі» [22, p. 356.]. Теодор Рузвельт був обурений європейською бездіяльністю у справі захисту вірменських християн від терору турків. Його ставлення до проблеми знищення вірменського населення в Османській імперії було незмінним впродовж багатьох років.

1899 року Рузвельт у листі до свого товариша, британського дипломата С. Спрінг-Райса, писав, що дуже шкодує, що Західна Європа не змогла покласти край правлінню турків. Як президент, Рузвельт обіцяв, що буде діяти від імені пригноблених османських християн, хоча він i обмежений формальною політикою невтручання. У 1905 р., реагуючи на продовження насильства проти вірмен, він визнав, що вартувало б відправити американські війська у хрестовий похід проти турків [29, р.242.].

Крайньою межею, яку охоплює засяг дії «великого кийка» Рузвельта є тубільні племена Азії, вочевидь тихоокеанських островів, які ідентифікуються за зовнішніми ознаками, і також скаржаться президенту на існування конфліктів. Причому слово «nation» тут може бути потрактоване і як «народність», «плем'я», тобто міжплемінні конфлікти, і як «держава», тобто як суперечки між великими державами за острівні володіння.

Країни Східної півкулі представлені на карикатурі Л. Делрімпла Великою Британією, Францією, Німеччиною, Росією, Японією та Китаєм. Всі вони звертаються до нового світового поліцейського зі скаргами на взаємні суперечки, непорозуміння і претензії.

Одна 3 відомих персоніфікацій образу Великої Британії Джон Булл, у традиційному одязі кольорів британського прапора (червоний сюртук, білі легінси, короткий циліндр), простягає до Т. Рузвельта корабель. Питання флоту завжди були пріоритетними 
для Т. Рузвельта. 3 початку своєї політичної кар'єри він методично обстоював потребу реалізації широкої морської програми. Долаючи спротив всередині Республіканської партії і поза нею, особливо у Конгресі, наполягав на тому, що політичну та економічну безпеку США може гарантувати лише збудований за останнім словом техніки та добре навчений військовоморський флот адекватних розмірів. Флот, казав Рузвельт, найдешевший i найефективніший страховий поліс миру для Сполучених Штатів, і фінансово вони спроможні збудувати його. Володіння військово-морським флотом - це єдиний засіб не дозволити нікому ігнорувати доктрину Монро. Американці не можуть розраховувати на вплив у міжнародній політиці ні в Атлантиці, ні в Тихому океані, якщо не матимуть ефективного військово-морського флоту [27, р. 109-117]. Вже 1898 р. новіший i краще підготовлений американський флот відіграв ключову роль у досягненні перемоги над Іспанією.

Втім питання збільшення торговельного флоту теж незмінно було у порядку денному передвиборчої програми республіканців. Зокрема, платформа 1904 р. передбачала надання пільг національним суднобудівельним заводам, без яких неможливо конкурувати із закордонними флотами, що обкладені низькими податками і субсидуються урядами [25].

Розбудова торговельного флоту США на межі XIX - XX ст. загрожувала серйозною конкуренцією флоту британському, який після відмови Англії від протекціонізму в галузі морських перевезень на загальних підставах змагався з іншими. Тому на карикатурі Джон Булл простягає Т. Рузвельту свій торговельний корабель, вимагаючи від президента справедливості щодо нього. Тут відображений намір Т. Рузвельта здійснювати будівництво американських торгових суден на власних верфях, що також зачіпало інтереси Британії, зі стапелів якої ще наприкінці XIX ст. сходила більшість торгових і військових кораблів великих країн.

Німеччина і Франція на карикатурі перебувають у традиційному протистоянні, адже з 1871 р. питання Ельзасу і Лотарингії незмінно стояло на шляху встановлення довірних відносин між державами.

Попри те, що головні вектори зовнішньої політики Т. Рузвельта були спрямовані на Карибський регіон і Латинську Америку, 
Далекий Схід не залишався поза його увагою. На малюнку Л. Делрімпла бачимо представників Росії та Японії, війна між якими на момент виходу у світ карикатури була у повному розпалі. Під час конфлікту президент займав виразно прояпонську позицію, оскільки вважав, що переважання Японії буде більш сприятливим для захисту американських інтересів у регіоні. Однак вже наприкінці 1904 р., коли перспектива японської перемоги стала очевидною, це викликало острах Т. Рузвельта, адже одноособове домінування Японії могло надміру порушити рівновагу на Далекому Сході. Подальша ініціатива президента бути посередником в японсько-російських мирних переговорах теж не в останню чергу була спричинена цим занепокоєнням. Посередництво мало на меті зберегти баланс сил на Далекому Сході, зробити вимоги Японії поміркованішими і запобігти можливому втручанню європейських держав, як це було після японсько-китайської війни 1894-1895 рр. Підтримка Рузвельтом Японії під час війни пояснювалася також його прагненням зберегти політичну стабільність у Європі. Адже Японія з 1902 р. була союзником Британіі, Британія - союзником Франції, і таким чином, програш Японії міг спричинити нові пертурбації у міждержавних відносинах в Європі [12, р. 318, 369-370].

Ключовим об'єктом інтересу США на Далекому Сході все більше ставав Китай. Його представник на карикатурі Л. Делрімпла легко впізнається за зовнішністю, традиційним одягом і маньчжурською косичкою. Вже у вересні 1899 p. дипломатична заява держсекретаря США Д. Хея проголосила доктрину «відкритих дверей» у Китаї, яка передбачала зрівняння можливостей європейських держав і США в їх доступі на китайський ринок [11].

Зображення Л. Делрімплом народів і країн світу відображають тогочасні типові уявлення про них американців. Усі вони легко ідентифікуються читачем за різними характерними ознаками i складають на нього негативне враження. Персоніфікації Свропи, а також Японії, представлені більшістю у військовій уніформі, деколи середньовічного зразка, як от німець у рицарських обладунках, зовні схожий на кайзера. Всі вони при зброї, розмахують шаблями, висувають претензії один одному i шукають підтримки Сполучених Штатів. Представники 
Близького і Середнього Сходу виглядають радше як персонажі «Казок тисячі й однієї ночі», що підкреслює тогочасні американські уявлення про них як відсталих, закостенілих на середньовічній стадії розвитку. Країни Америки та Океанії охоплені хаосом, часом схожі на жебраків з простягнутою до США рукою.

Карикатура Л. Делрімпла «Світовий поліцейський» була i влучним відображенням уявлень американців про роль у світі США. Охопивши майже всі найважливіші вектори американської зовнішньої політики відповідно до установок Поправки Рузвельта до доктрини Монро, карикатура промовисто доносила цю інформацію до читачів. Досліджуваний період був золотим віком американської політичної карикатури, коли публікувалися тисячі малюнків у численних сатиричних, і не лише, виданнях, як от «Harper's Weekly», «Puck», «Judge», «New York Daily Graphic», «Frank Leslie's Illustrated Newspaper», тощо [13]. Тоді ж, коли був опублікований «Світовий поліцейський» Л. Делрімпла, на шпальтах цих видань читачі мали можливість побачити більше сорока карикатур, на яких зображений президент Рузвельт із великим кийком у руках як символ нових зовнішньополітичних пріоритетів США; більше тридцяти візуальних рефлексій карикатуристів з приводу політики Т. Рузвельта у Карибському регіоні; близько п’ятдесяти карикатур, що трактують президента як відвертого імперіаліста [9]. Безвідносно до того, чи ці малюнки, як і карикатура Л. Делрімпла, містили пряме чи латентне схвалення нової дипломатії Т. Рузвельта, чи засуджували ії, вони конструювали у свідомості американців нову даність зовнішньополітичних інтересів США.

Висновки. Карикатура «Світовий поліцейський» Л. Делрімпла може бути потрактована як репрезентація зовнішньополітичної ідентичності американців кінця XIX - початку XX ст. Звертає на себе увагу стереотипність образів держав і народів, представлених Л. Делрімплом. Єдиним по-справжньому «цивілізованим» персонажем малюнка виглядає лише сам Рузвельт-поліцейський. Свропейці, латиноамериканці, азіати відрізняються тільки ступенем своєї відсталості. Якщо аристократично-монархічні європейці представляють стару цивілізацію, відсталу у контекстів своїх політичних режимів, представники Близького і Середнього Сходу застрягли у часі середньовіччя, то представники азійсько-тихоокеанського 
регіону виглядають цілковитими варварами. Сполучені Штати презентуються як єдина реальна сила, здатна вирішити всі непорозуміння між зображеними країнами.

Л. Делрімпл прямо жодним чином не схвалює і не засуджує новий курс зовнішньої політики США, керований Поправкою Рузвельта до доктрини Монро. Однак композиційна організація карикатури, характер персонажів, конкретно-історичний контекст малюнка дає можливість зробити висновок про прихильність художника до ролі США як світового поліцейського задля врегулювання міжнародних криз і залучення в орбіту цивілізації відсталих народів.

Чітке протиставлення США решті світу здійснено у категоріях сила - слабкість, порядок - безпорядок, цивілізація - варварство, демократія - деспотизм, мир - війна. Будучи опублікованою у масовому популярному часописі «Judge», карикатура «Світовий поліцейський» Л. Делрімпла разом із десятками і сотнями подібних малюнків у інших виданнях відображала i водночас впливала на конструювання зовнішньополітичної самоідентифікації американців.

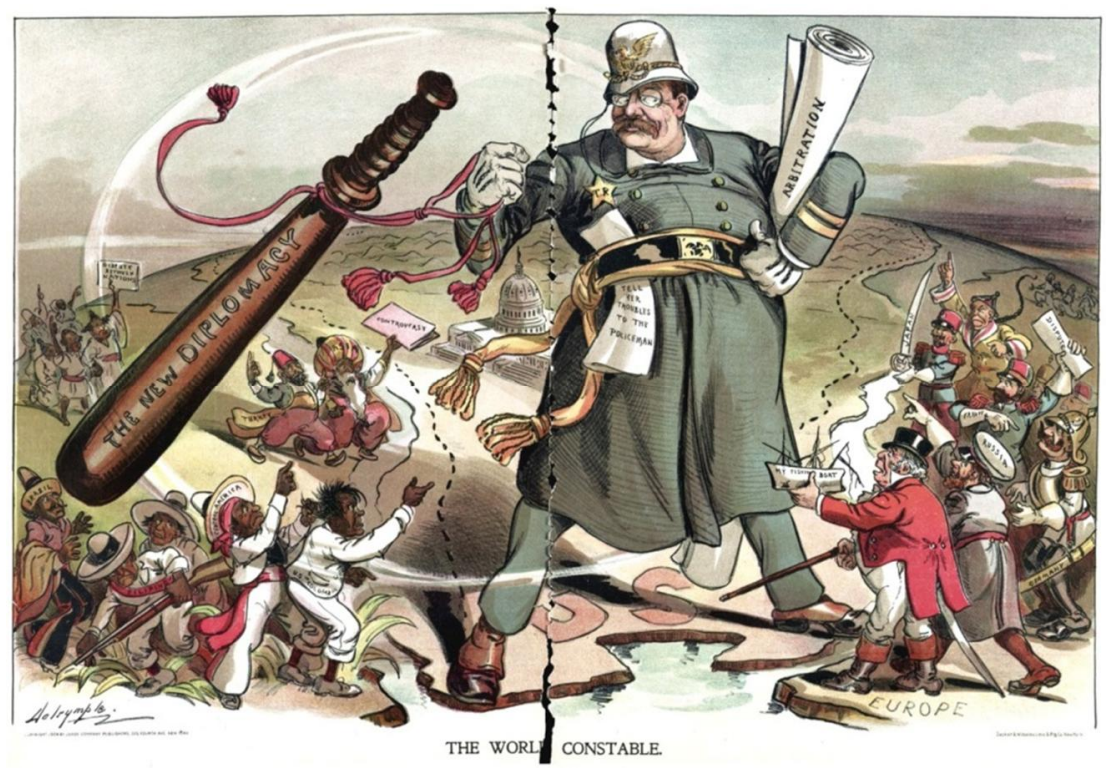


1. Журавлева. В.И. История российско-американских отношений как имагологическое исследование: методология и историографическая практика // История: электронный научно-образовательный журнал. 2010-2012. Вып.4: История США// http:/mes.igh.ru/magazine/content/usa_imagology.html;

2. Журавлева В.И. Русский «Другой» в американской политической карикатуристике: от века XIX к веку XXI // Вестник РГГУ. Серия «Международные отношения. Регионоведение». 2012. № 7 (87). - С. 64-96.

3. Касаткіна $К$. Місце Куби серед зовнішньополітичних інтересів США (XIX - середина XX ст.) // Американська історія та політика. 2016. № 2. С. 191-197;

4. Киссинджер Г. Дипломатия: Пер. с англ. Москва: «Ладомир»: ТОО «ВРС», 1997. 848 с.

5. Лукач I. Розвиток доктрини Монро як концептуальної основи політики США в Латинській Америці (кін. XIX поч. $\mathrm{XX}$ ст.) // Вісник Київського національного університету імені Тараса Шевченка. Історія. 2013. Вип. 1. C. $38-40$.

6. Питльована Л.Ю. Глобалізація американської зовнішньої політики наприкінці XIX - на початку XX століття: військові аспекти// Військово-науковий вісник. 2009. Вип.12. Львів: АСВ, 2009. С.93-105.

7. Питльована Л. Ю. Роль президента В. Вільсона у Першій світовій війні та повоєнному врегулюванні в Європі очима британських карикатуристів // Військовонауковий вісник. Вип.23. Львів: АСВ, 2015. С.266-279.

8. Питльована Л.Ю. Теодор Рузвельт: реформізм та експансія у США на зламі XIX-XX століть // Військовонауковий вісник. 2009. Вип.11. Львів: АСВ, 2009. С.150-164.

9. The Almanac of Theodore Roosevelt. Cartoons // http://www.theodore-roosevelt.com/trcartoonsprompt.html

10.Brody D. Visualizing American empire : orientalism and imperialism in the Philippines. Chicago: University of Chicago Press, 2010. 213 p.

11.Commercial Rights in China ("Open Door" Policy): Declarations by France, Germany, the United Kingdom, Italy, Japan, and Russia accepting United States proposal for "open door" policy in China, September 6, 1899-March 20, 1900 // https://www.loc.gov/law/help/us-treaties/bevans/must000001-0278.pdf

12. A companion to Theodore Roosevelt / ed. by Ricard S. Chichester; Malden, Mass.: Wiley-Blackwell, 2011. 584 p. P. 318, 369-370. 
13. Culbertson T. The Golden Age of American Political Cartoons // The Journal of the Gilded Age and Progressive Era. 2008. Vol. 7. No. 3. P. 276-295.

14. Dalrymple L. The world's constable // http://www.loc.gov/p ictures/item/2014645367/

15.Duke S.W. Biographical sketches of cartoonists \& illustrators in the Swann Collection of the Library of Congress. Arlington, VA: ComicsDC, 2012. P. 74

16. The Evening World. November 25, 1905. P. 3.

17.Hart A. B. The United States as a World Power. A Chapter of National Experience // Harper's New Monthly Magazine. Dec. 1898 - May 1899. P.485-494.

18.Hendrickson Embert J. Roosevelt's Second Venezuelan Controversy // The Hispanic American Historical Review. 1970. Vol. 50. No. 3. P. 484-485

19. Judge Magazine Illustration Collection. A Finding Aid to the Collection in the Helen Farr Sloan Library \& Archives, Delaware Art Museum // http://www.delart.org/wordpress/wpcontent/uploads/2017/11/Judge-Magazine.pdf

20.Korhonen P. The Pacific Age in World History // Journal of World History. 1996. Vol. 7. No. 1. P. 41-70.

21.Marschall R. Bully!: the life and times of Theodore Roosevelt: Illustrated with More Than 250 Vintage Political Cartoons. Washington, DC: Regnery Publ., 2011. 440 p.

22. Oren $M$. B. Power, faith, and fantasy3: America in the Middle East, 1776 to the Present. New York: W.W. Norton \& Company, 2008. 864 p.

23.President Theodore Roosevelt's Annual Message to Congress, December 6, 1904 / http://www.presidency.ucsb.edu/ws/index.php?pid=29545

24.Rauchway E. Murdering McKinley: The Making of Theodore Roosevelt's America. New York: Hill and Wang, 2003. 250 p.

25. Republican Party Platform of 1904 (June 21, 1904) // http://www.presidency.ucsb.edu/ws/index.php?pid=29631

26. Roosevelt Th. State of the Union Message. December 3, 1901 / http://www.theodore-roosevelt.com/sotu1.html

27. Roosevelt Th. World Feats. Speech at Omaha 2.09.1910 / Roosevelt T. The New Nationalism. Gloucester: Mass. Peter Smith, 1971. P.109-117.

28. Wales, James Albert / Appletons' Cyclopædia of American Biography / td. by John Fiske, James Grant Wilson. In 6 vol. Vol. 6. New York: D. Appleton and Company, 1889. 809 p. P. 323 
29. Walther K. V. Sacred interests: the United States and the islamic world, 1821-1921. Chapel Hill: The University of North Carolina Press, 2015. 457 p.

Надійшло до редколегії 17.09.2018 p.

\section{Pytlovana L. \\ AMERICANS' FOREIGN POLICY IDENTITY IN AMERICAN POLITICAL CARTOONS OF EARLY 20TH CENTURY: «WORLD'S CONSTABLE» BY LOUIS DALRYMPLE}

This article examines visual representations of $\mathrm{T}$. Roosevelt's foreign policy in «World's constable» political cartoon by Louis Dalrymple. The author's analysis of the cartoon sheds light on Americans' attitude towards the US new international role as the police power according to the Roosevelt Corollary to the Monroe Doctrine. The study of L. Dalrymple's biography, the Judge history, an analysis of particular historical context of the cartoon, makes it possible to consider it as an important source to the history of US foreign policy of the end of 19th - on the beginning of 20th centuries, as well as a representation and an instrument for the construction of Americans' foreign policy identity.

Keywords: foreign policy, cartoon, identity, Louise Dalrymple, Theodore Roosevelt, USA 